\section{New business models: Beyond the shareholder approach}

\author{
Leire Alcaniz ${ }^{1}$ \\ ${ }^{1}$ University of Deusto, Department of Finance and Accounting, Bilbao, Spain
}

Ricardo Aguado

Jose Luis Retolaza ${ }^{2}$

${ }^{2}$ University of Deusto, Department of Economics, Bilbao, Spain
Received on

04/09/2018

Approved on

07/03/2019

\section{Responsible editor:}

Prof. Dr. João Mauricio Gama

Boaventura

Evaluation process:

Double Blind Review

\begin{abstract}
Purpose - The first objective of this paper is to explain and compare new business models that are currently being successfully applied worldwide. The second objective is to carry out an empirical analysis to observe the perception of experts regarding these models, the differences between them, and their orientation toward the traditional theory of the firm or the stakeholder approach in some of the characteristic elements of the organizational structure of the firm.
\end{abstract}

Design/methodology/approach - In a first step we conduct a literature review that compares the dominant theory of the firm (neoclassical model) with the stakeholder theory. Secondly, we present six additional business models and compare them with both the neoclassical and stakeholder approaches. In a second part of the paper we use a fuzzy Delphi methodology in order to collect qualitative information from a group of experts about those six additional business models.

Findings - The stakeholder approach is a valuable explanatory tool to address how firms can generate a broader positive impact at the social level. Identifying the stakeholders that interact within the firm allows the firm's managers to take into account their specific needs, which are usually not limited to profit maximization.

Originality/value - Emerging business models can benefit from the stakeholder approach to integrate those needs due to an organizational structure focused on stakeholders' interests.

Keywords - Stakeholder theory, fuzzy Delphi, business models

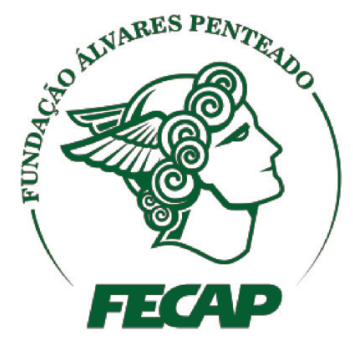

Review of Business Management 


\section{Introduction}

In the present socio-economic context, the neoclassical economic system has a growing number of detractors who are conscious about its limitations (Garriga \& Melé, 2004). The dominant theory of the firm defends the maximization of shareholder value as a key element for decision-making (Jensen \& Meckling, 1976). The maximization behavior endorsed by the dominant economic paradigm does not seem particularly oriented towards building a better and sustainable economy in the long-term. In fact, many economists have underlined the ethical deficit in economic structures (Naughton, 2015) or the need for a humanistic approach to economics and business, especially after the financial crisis (Melé \& Schlag, 2015). In contrast with the traditional theory of the firm, stakeholder theory considers all stakeholders involved in an organization, promotes a decision-making system that considers different interests, and tries to maximize stakeholder value (Freeman, 1984).

In fact, it could be accepted that the stakeholder approach has, to a great extent, displaced the model focused on shareholder value maximization. As specified in a study of 100 firms taken from the Fortune 500, only 10 firms were found to champion an emphasis on shareholder value maximization. Another 22 endorsed a shareholder focus that was "legally and ethically designed," while 64 adopted the approach of "maximizing the welfare of all stakeholders," and 2 aimed to solve "social problems obtaining fair profit at the same time" (Agle et al., 2008). Today, it may seem that the trend in favor of stakeholder theory continues. However, this perception could be misleading. In 2007, the Academy of Management organized a symposium on the future of stakeholder theorizing in business, where it was discussed if stakeholder theory had generated a real change in management or had just facilitated the use of new terminology (Agle et al., 2008). Currently, the situation has not changed substantially. In almost all universities in the world, the classical microeconomic model prioritizing profit maximization and the creation of value for shareholders is still taught (Aguado, Alcaniz, \& Retolaza, 2015). It could be acknowledged that stakeholder theory has been accepted by corporations from an instrumental point of view, but it has not been used in the construction of an alternative model to understand the functioning of the firm (a new theory of the firm) (Donaldson \& Preston, 1995). In fact, the scholar that firstly developed stakeholder theory proposes in his latest papers the need for a new narrative for businesses based on stakeholder theory in order to understand how firms should be managed (Freeman \& Ginena, 2015). In this new narrative, the search for existing cases with explanatory power is a key element (San-Jose, Retolaza, \& Freeman, 2017).

With the intention of identifying business models that are helpful in implementing a stakeholder orientation, the first objective of this study is to analyze the main differences between the shareholder approach and stakeholder theory, and then explain and compare new business models that are currently being successfully applied worldwide which are close to stakeholder theory. The second objective is to carry out an empirical analysis to observe the perception of experts regarding those models, the differences between them, and their orientation towards this new narrative. Through this analysis our final aim is to show that, according to a panel of experts, the principles of the new narrative for businesses are compatible with different business models. This could be a relevant contribution to stakeholder theory, and for managers looking for a way to implement the principles of stakeholder theory in their organizations

After the introduction, we will present a systematic analysis of both the current shareholder approach and stakeholder theory. In both cases we will use a microeconomic perspective, since that is the one that defines the behavioral patterns of firms, individuals, and families. We will consider the goal of the firm, property rights, 
contractual ties, value generation, trust, and governance, concluding that the two approaches differ regarding those elements. In section three, we will analyze the six most relevant business models that incorporate an orientation towards stakeholders as part of their own aims, and not only as an instrumental behavior to maximize shareholder value: economy of communion, social economy, solidarity economy, economy for the common good, B-Corps, and blue economy. In the fourth section, we will observe, through an empirical exploration, whether a group of experts share a consensus on the main characteristics of these new business models or not, and whether this consensus corroborates the analysis made in section 3. Finally, we will present our conclusions, recognize the limitations of this study, and propose future lines of research.

\section{The Shareholder Approach versus Stakeholder Theory}

Modern and unorthodox conceptions of the firm try to stress not only the importance of profits, but also the social responsibility of the firm, which should take into account customers, suppliers, workers, public administrations, and the social environment (stakeholder-based approach) (Freeman \& Ginena, 2015); whereas the traditional neoclassical thinking proposed that the social responsibility of business is to increase its profits (shareholder-based approach) (Friedman, 1970).

Nevertheless, even within mainstream economics, some authors state that only taking shareholders' interests (maximizing short-term profit) into account may undermine a firm's productive potential, because this type of behavior does not offer incentives for stakeholders to make specific commitments to the firm (Keay, 2007). Along these same lines, other authors suggest that economic value in a given firm is created by the cooperation between the different stakeholders that converge in that firm (Melé \& Schlag, 2015). Therefore, the main objective of the firm should be to create value propositions that are interesting for all stakeholders (Freeman \& Ginena, 2015). Profits would then be a consequence of developing value propositions that are appealing for stakeholders, and not the aprioristic aim of the firm (Aguado et al., 2015).

This reasoning has been echoed by many mainstream theorists, who now accept the need to consider broad stakeholders' interests and not only shareholders' interests (Jensen, 2001). As a result, some corporations have started to adopt a triple approach to performance measurement that includes indicators pertaining to three different dimensions: profit, people, and planet (Elkington, 1998).

There seems to be a growing consensus on the need for a transformation of the dominant social and economic model in order to promote higher levels of justice and equality. However, it is difficult to find coherent proposals to implement this shift. We believe that it is important to modify the basic ideas about the role, the mission, and the objectives of the firm by articulating an alternative theory of the firm.

A theory of the firm is understood to develop the conceptual framework that states what a firm is and what role it should have in society and in the economy. This theoretical development serves as a basis for the legal and cultural systems surrounding the firm. Currently, the dominant theories of the firm focus almost exclusively on the value generated for shareholders (Coase, 1937) and are based on four pillars: property rights theory (Demsetz, 1967), transaction cost theory (Coase, 1960), contract theory (Barnett, 1986), and agency theory (Jensen \& Meckling, 1976) (see first column in table 1).

The following table (table 1) presents a comparison between the dominant theory of the firm (shareholder theory) and stakeholder theory. At the same time, we present the theoretical foundation of the new narrative for businesses based on stakeholder theory. 


\begin{tabular}{|c|c|c|c|}
\hline & $\begin{array}{l}\text { DOMINANT THEORY: } \\
\text { SHAREHOLDER THEORY }\end{array}$ & $\begin{array}{l}\text { ALTERNATIVE THEORY: } \\
\text { STAKEHOLDER THEORY }\end{array}$ & $\begin{array}{l}\text { THEORETICAL FOUNDATION OF THE } \\
\text { NEW NARRATIVE OF STAKEHOLDER } \\
\text { THEORY (San-Jose et al., 2017; Freeman \& } \\
\text { Ginena 2015) }\end{array}$ \\
\hline \multirow{2}{*}{ 至 } & PROFIT MAXIMIZATION & $\begin{array}{l}\text { VALUE MAXIMIZATION } \\
\text { (BENEFIT) }\end{array}$ & THE PURPOSE PRINCIPLE \\
\hline & $\begin{array}{l}\text { The main objective of the } \\
\text { firm is short-term profit } \\
\text { maximization for shareholders. }\end{array}$ & $\begin{array}{l}\text { Value is not only the financial result, } \\
\text { but also the total wealth generated by } \\
\text { the firm through all the operations it } \\
\text { performs. }\end{array}$ & $\begin{array}{l}\text { Organizations are driven by a wider purpose than } \\
\text { mere profit (Freeman, 1999)). }\end{array}$ \\
\hline \multirow[b]{2}{*}{ 究 } & UNLIMITED & SHARED & THE HUMAN COMPLEXITY PRINCIPLE \\
\hline & $\begin{array}{l}\text { Capital is the main resource } \\
\text { of the firm. Property rights } \\
\text { over capital are converted into } \\
\text { property rights over the firm. } \\
\text { Shareholders are the owners of } \\
\text { the firm. }\end{array}$ & $\begin{array}{l}\text { The resources used by the firm are } \\
\text { broader than just financial capital. } \\
\text { Social, intellectual, natural, cultural, } \\
\text { and reputational capitals also } \\
\text { contribute to the value generation } \\
\text { process. }\end{array}$ & $\begin{array}{l}\text { The reductionism of homo economicus does not } \\
\text { correspond to reality; aspects such as career } \\
\text { development, social interaction, or even a sense of } \\
\text { transcendence, may have much greater value than } \\
\text { a mere financial transaction (Freeman, Stewart, \& } \\
\text { Moriarty, 2009). }\end{array}$ \\
\hline \multirow[b]{2}{*}{ 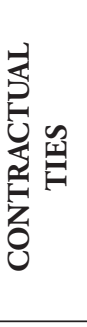 } & UNCONDITIONAL & SYMMETRICAL & THE VALUE CREATION PRINCIPLE \\
\hline & $\begin{array}{l}\text { Entrepreneurial relations are } \\
\text { formalized through contracts, } \\
\text { and the only limits are legal } \\
\text { regulations. The firm is defined } \\
\text { as a contractual network. Logic } \\
\text { of the law. }\end{array}$ & $\begin{array}{l}\text { Contracts should be ruled by the law } \\
\text { and incorporate fair conditions for all } \\
\text { parties regarding information, power, } \\
\text { and general conditions. Logic of } \\
\text { exchange. }\end{array}$ & $\begin{array}{l}\text { Value creation for stakeholders is the foundation } \\
\text { of any business activity (Freeman \& Liedtka } \\
\text { 1991; Freeman, Kirsten, \& Parmar, 2007). } \\
\text { Businesses create value, or destroy it, for a broad } \\
\text { range of stakeholders: employees, suppliers, } \\
\text { customers, the state, society, and so on, and not } \\
\text { just for one of them, namely, shareholders. }\end{array}$ \\
\hline \multirow[b]{2}{*}{ 厹晃 } & $\begin{array}{l}\text { TRANSACTION COST } \\
\text { THEORY }\end{array}$ & SOCIAL VALUE THEORY & THE INTERCONNECTION PRINCIPLE \\
\hline & $\begin{array}{l}\text { Value generation is achieved by } \\
\text { the reduction of costs. R\&D } \\
\text { and technological innovation } \\
\text { are directed towards production } \\
\text { efficiency. }\end{array}$ & $\begin{array}{l}\text { Value generation is achieved through } \\
\text { higher value that the firm's products or } \\
\text { services create for all stakeholders. }\end{array}$ & $\begin{array}{l}\text { A corporation creates value through interactions } \\
\text { and mutual benefit among people (Freeman, } \\
\text { 2008). In this sense, the creation of shared value } \\
\text { and the equilibrium in its distribution among } \\
\text { shareholders become key elements for managers } \\
\text { (San-Jose et al., 2017). }\end{array}$ \\
\hline \multirow[b]{2}{*}{ 点 } & AGENCY THEORY & STEWARDSHIP THEORY & RECIPROCITY PRINCIPLE \\
\hline & $\begin{array}{l}\text { The individual is a rational } \\
\text { decision-maker who will try to } \\
\text { maximize his/her own interest } \\
\text { at the expense of others, even } \\
\text { in the case of fiduciary duty on } \\
\text { behalf of a principal. }\end{array}$ & $\begin{array}{l}\text { Egocentric and opportunistic behavior } \\
\text { by managers should not be accepted } \\
\text { as a rule. Managers should seek shared } \\
\text { value for all stakeholders. }\end{array}$ & $\begin{array}{l}\text { The dealings between customers, suppliers, } \\
\text { employees, communities, and financial backers } \\
\text { create business operations, and their development } \\
\text { not only requires these stakeholders' involvement, } \\
\text { but also has a positive or negative impact upon } \\
\text { them throughout the entire value creation process } \\
\text { (Freeman, Harrison, Wicks, Parmar, \& deColle, } \\
\text { 2010). }\end{array}$ \\
\hline \multirow[b]{2}{*}{ 至 } & $\begin{array}{l}\text { CENTRALITY OF } \\
\text { SHAREHOLDERS }\end{array}$ & $\begin{array}{l}\text { MULTI-STAKEHOLDER } \\
\text { GOVERNANCE }\end{array}$ & COOPERATION PRINCIPLE \\
\hline & $\begin{array}{l}\text { The rights of stakeholders } \\
\text { are contractually guaranteed. } \\
\text { Shareholders are the only ones } \\
\text { bearing the risks of the firm's } \\
\text { economic activity. As a result, } \\
\text { they are entrusted with the } \\
\text { governance of the firm. }\end{array}$ & $\begin{array}{l}\text { If financial capital is not the only } \\
\text { resource that generates value and the } \\
\text { risk of economic activity is shared by } \\
\text { all stakeholders, then governance of } \\
\text { the firm should not be associated only } \\
\text { with the rights of shareholders. Multi- } \\
\text { stakeholder governance is needed. }\end{array}$ & $\begin{array}{l}\text { The different stakeholder groups in a firm } \\
\text { (employees, suppliers, financial backers, } \\
\text { customers...) provide resources and capabilities } \\
\text { for creating value jointly. Accordingly, } \\
\text { cooperation, and not conflict, facilitates the value } \\
\text { creation process (Dunham, Freeman, \& Liedtka, } \\
\text { 2006). }\end{array}$ \\
\hline
\end{tabular}




\section{Emerging Business Models}

The last few decades have witnessed the appearance of business models that differ from the traditional system. In this section, we will focus on six important alternative models to capitalist businesses: the economy of communion, the social economy, the solidarity economy, the economy for the common good, B-Corps, and the blue economy. These six business models have been identified through a bibliographical analysis considering results from the last 10 years in the Web of Science (WoS), considering all papers in management and economics which had in their keywords "model," "alternative," and "stakeholder." All of them are structured systemic alternatives and have been endorsed by practical experiences. We will briefly describe the main characteristics of each model and then analyze to what extent these new models are closer to stakeholder theory.

\section{I The economy of communion}

The economy of communion (EC) has its roots in the Focolare Movement (part of the Catholic Church), created by Chiara Lubich in Trento (Italy) during the $2^{\text {nd }}$ World War. This movement organized a community of sharing, based on fraternity and unity (Lubich, 2007). The EC was born when the Focolare Movement tried to fight against the structural inequalities of the economy by creating new businesses or transforming the existing ones. In doing so, the EC generated employment and resources that helped people to get out of poverty under the principle of profit sharing (Gold, 2013).

The main idea of this movement consists of creating profitable firms that contribute to decreasing income inequalities and benefit the poor through the market economy (Guitián, 2010). However, their profits are not delivered to shareholders, but instead allocated to three different objectives: one-third of the profit is invested in the firm in order to maintain or enhance its level of competitiveness; another one- third is used to help people in need, particularly those in the community where the firm is located; and the remaining one-third is devoted to the dissemination of the culture of the economy of communion both locally and globally. Instead of using a short-term profit maximization pattern, these companies are managed with a long-term vision, considering all stakeholders (Bruni \& Zamagni, 2004; Lubich, 2007).

These organizations create wealth and redistribute it. This creates a paradigm shift, considering that usually firms create wealth and the public administration redistributes it. The management of the firm also differs from the classical theory of the firm, in the sense that they try to build long-term and mutually profitable relationships with stakeholders. Apart from poor people, to whom they allocate a third of the profit, they consider the different stakeholders as partners that will make the business more competitive in the long-term (Héjj, 2011).

\subsection{The social economy}

There is no consensus when talking about social and solidarity economies and these concepts are often used indifferently. In this paper, we will distinguish between them according to their initial fundamental objectives and property distribution.

The social economy was born thanks to the associative impulse in the $19^{\text {th }}$ century to fight against the detrimental conditions of the industrial revolution and to ensure self-help among workers of the industrial sector to achieve better working conditions (Monzón \& Chaves, 2012). Organizations working in the social economy have some factors in common. First, people taking part in the firm must have taken the decision freely. The decision-making is democratic, meaning that the property of the organization is in the hands of the employees, and every associated employee has a vote independently of the amount invested. The most common situation is when every associate has the same percentage of the firm's capital. This ensures that individuals do 
not accumulate profit. At the same time, this kind of organization promotes solidarity within the group and tries to achieve not only economic sustainability for the future, but also promote social aspects and individual development. In order to achieve economic and social objectives, these organizations offer quality products or services. Thus, they carry out a business activity, usually with a profit orientation (European Network of Social Economy Foundations, 2000).

These are the main characteristics of the social economy and, basically, cooperatives and mutual companies are the types of corporation that fulfill them. The social economy thus uses the market to meet social goals and their organizations are usually independent from public power (Lewis \& Swinney, 2008).

\subsection{The solidarity economy}

The organizations inside the solidarity economy are born with the aim of meeting public needs, promoting internal solidarity, as well as solidarity towards the community. These organizations are involved with local development, equal opportunities, social cohesion, the generation of quality employment, the reconciliation of work and family life, and sustainability, carrying out activities related to health, education, culture, the environment, and social housing. They are organizations focused frequently on social exclusion, which work in the so-called third system, this is, voluntary organizations, associations, and foundations (Retolaza, Mugarra, \& Enciso, 2005).

According to its fundamental principles, profits are not allocated based on any proportionality criteria with respect to capital. The owners and employees renounce obtaining market returns or market salaries in order to have more funds in the organization to help people and society to satisfy their needs. In fact, solidarity economy organizations have a 'distributive' nature where stakeholders are not focused just on monetary compensation (Bacchiega \& Borzaga, 2003).
In short, the solidarity economy fights for a generalization of democracy, not only in the political sphere, but also in the economic sphere (Dacheux \& Goujon, 2011).

\subsection{The economy for the common good (CG)}

In order to make it easier for organizations to know how to make decisions that seek the good of all, Felber (2015) proposes a practical development of the economy for the common good, identifying and ranking firms according to their contribution to social well-being. Firms are evaluated by means of the so-called common good matrix, which considers five variables: human dignity, cooperation and solidarity, environmental sustainability, social justice, and democratic participation and transparency. These variables are analyzed with respect to five interest groups: suppliers, investors, employees (including business owners), customers and business partners, and society at large. The matrix measures positive and negative criteria; this is, organizations must also consider any detrimental action against the common good, such as: violation of international standards related to labor, the environment, dumping prices, etc. Firms will get a score out of 1,000 points. Good practices will add points, while negative ones will reduce them. A firm based on the traditional model would get between 0 and 100 points. The objective for those firms interested in this movement would be to improve their score over time.

The economy for the CG promotes the transfer of firm ownership to employees and democratic decision-making considering employees and local stakeholders in fundamental strategic issues. These organizations could reduce their dividend payments in order to strengthen their financial structure, and to avoid pressure on employees' labor conditions and on other stakeholders, such as suppliers, to increase profit and maximize shareholder returns. This model also recommends the development of reporting processes for internal and external stakeholders (Felber, 2015). 


\subsection{B-Corps}

B-Corp is a project that was originally launched in the US and has spread worldwide. It is now legally recognized in many US states and in Italy as a new corporate form (benefit corporation). B-Corp is a business certification awarded by a non-profit organization called B-Lab (there are more than 1,700 certified B-Corps throughout the world). B-Lab studies if a company meets certain standards regarding social and environmental performance, accountability, and transparency. Any firm wishing to become a B-Corp must complete an assessment, write a report, and submit any necessary supporting documents. Depending on the degree of agreement with the B-Corp principles, the company will earn points. It needs 80 out of approximately 200 points to get the certification. Any firm can complete the assessment and see what their strengths and weaknesses are (Bcorp, 2014).

One of the characteristic factors in B-Corps is that they specify in their mission and statutes other objectives apart from profit maximization, related to corporate social responsibility (CSR). They protect that mission legally; this is, directors and shareholders are legally protected to make decisions considering the interests of all stakeholders. B-Corps will be able to make decisions in favor of different stakeholders and not only shareholders. It is a way to fight against shareholder primacy and introduce stakeholders' interests in the fiduciary duties of directors (Hiller, 2013).

B-Corp firms are for-profit firms, with the usual corporate governance structure, private ownership, private funding, and market control. However, B-Corps recognize traditional businesses' weaknesses and agree to add social and environmental goals to their economic goals, through innovative organizational designs and accountability mechanisms (André,
2012). In addition, they develop transparency and accountability as key aspects, which are implemented through the publication of reports, available to the public, based on the triple bottom line approach (social, environmental, and economic). In this way, stakeholders (investors, customers, or employees) can identify companies with a long-term commitment to become a B-Corp (Hiller, 2013).

\subsection{The blue economy}

The blue economy (BE) (or ZERI's philosophy in action) concept was created by Gunter Pauli in 2004, based on his first initiative ZERI (Zero Emissions Research and Initiatives), an initiative to design a new business model without emissions or waste and supported by the United Nations Development Program. The main idea of ZERI was based on the notion of ecosystem and nature, which does not produce waste or emissions (Pauli, 2010).

The model seeks to achieve efficiency by following the logic of natural systems, making innovative products and services available to all, solving social problems without a negative impact on the environment, and enabling firms to be competitive in the market. The objective of businesses in the $\mathrm{BE}$ is to use innovation to produce or to carry out their activity without generating waste. This does not mean that corporations should just use fewer chemical products, or renewable sources of energy, but shift towards a new production paradigm. In this paradigm, industries would use the same physical patterns used by nature, e.g. re-utilizing byproducts to avoid waste (Pauli, 2015). Following the BE standard, firms carry out their activity without harming the environment, and in a sustainable way (Pauli, 2010).

Table 2 shows the comparison between the six alternative models presented above. 
Table 2

\section{Comparison of the six business models}

\begin{tabular}{llll}
\hline ECONOMY OF COMMUNION & SOCIAL ECONOMY & SOLIDARITY ECONOMY \\
\hline $\begin{array}{l}\text { The aim of the firm is to make a positive } \\
\text { contribution to the social and economic } \\
\text { development of people and countries. }\end{array}$ & $\begin{array}{l}\text { Mutual collective benefit. Profit } \\
\text { maximization. }\end{array}$ & $\begin{array}{l}\text { Fight against inequalities and towards } \\
\text { social, economic, and environmental } \\
\text { justice. }\end{array}$ \\
\hline $\begin{array}{l}\text { Property rights are an instrument oriented } \\
\text { towards the achievement of the common } \\
\text { good. }\end{array}$ & $\begin{array}{l}\text { Employees have ownership of the } \\
\text { firm; they are the shareholders. } \\
\text { Each member of the organization } \\
\text { has a vote independently of their } \\
\text { contribution. }\end{array}$ & Indivisible collective ownership. \\
& & &
\end{tabular}

\begin{tabular}{|c|c|c|c|}
\hline 量 & $\begin{array}{l}\text { Reciprocity between stakeholders is the } \\
\text { minimum required. Gratuity and the logic } \\
\text { of the gift apply as organizing principles. }\end{array}$ & $\begin{array}{l}\text { Distributive nature. Employees are } \\
\text { the owners of the firm. }\end{array}$ & Solidarity and mutual support. \\
\hline 点 & $\begin{array}{l}\text { Value is generated by the capacity of the } \\
\text { firm to generate access to human rights } \\
\text { and material and spiritual dignity. }\end{array}$ & $\begin{array}{l}\text { Search for social value (in the } \\
\text { community or for a specific group } \\
\text { of people). }\end{array}$ & $\begin{array}{l}\text { 'Values' generation: } \\
\text { Support of the values of each } \\
\text { community. } \\
\text { Promotion of democracy in the } \\
\text { whole society where the organization } \\
\text { works. }\end{array}$ \\
\hline 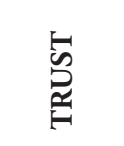 & $\begin{array}{l}\text { A management style based on reciprocity } \\
\text { and gratuity generates trust among the rest } \\
\text { of the stakeholders. }\end{array}$ & $\begin{array}{l}\text { Democracy in decision-making } \\
\text { increases trust. }\end{array}$ & $\begin{array}{l}\text { Trust is developed by the common } \\
\text { "mission" of solidarity in which all } \\
\text { employees are engaged. }\end{array}$ \\
\hline \multirow{2}{*}{ 至 } & $\begin{array}{l}\text { The ownership of the firm considers and } \\
\text { welcomes stakeholder participation in the } \\
\text { governance process. }\end{array}$ & $\begin{array}{l}\text { Development of a democratic } \\
\text { management style. }\end{array}$ & $\begin{array}{l}\text { Democratic decision-making and } \\
\text { shared responsibility. }\end{array}$ \\
\hline & $\begin{array}{l}\text { ECONOMY FOR THE } \\
\text { COMMON GOOD }\end{array}$ & B-CORPS & BLUE ECONOMY \\
\hline 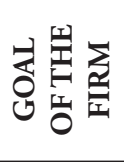 & $\begin{array}{l}\text { Contribution to the common good in } \\
\text { terms of solidarity, democracy, social } \\
\text { justice, transparency, human dignity, and } \\
\text { environmental sustainability. }\end{array}$ & $\begin{array}{l}\text { Economic goals (profit) and CSR } \\
\text { objectives. }\end{array}$ & $\begin{array}{l}\text { Follows the logic of natural } \\
\text { systems for business activity, } \\
\text { minimizing environmental impact of } \\
\text { corporations. }\end{array}$ \\
\hline 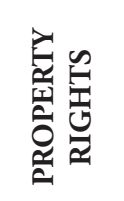 & $\begin{array}{l}\text { Promotion of distribution of ownership } \\
\text { among employees. }\end{array}$ & $\begin{array}{l}\text { Shareholders are the owners of the } \\
\text { company, but they have accepted } \\
\text { that directors will also consider } \\
\text { other stakeholders when making } \\
\text { decisions. }\end{array}$ & $\begin{array}{l}\text { Shareholders are the owners of the } \\
\text { firm. }\end{array}$ \\
\hline 总 & $\begin{array}{l}\text { Contracts should follow the international } \\
\text { standards and set fair conditions for all } \\
\text { parties. }\end{array}$ & $\begin{array}{l}\text { Directors have an extended } \\
\text { fiduciary duty not only to } \\
\text { shareholders but to the other } \\
\text { stakeholders and the environment. }\end{array}$ & $\begin{array}{l}\text { Contracts should follow the logic of } \\
\text { nature and contribute to the ZERI } \\
\text { principles. }\end{array}$ \\
\hline
\end{tabular}




\begin{tabular}{|c|c|c|c|}
\hline 兄兑 & $\begin{array}{l}\text { Value must be distributed among all the } \\
\text { stakeholders including society in general. }\end{array}$ & $\begin{array}{l}\text { For-profit companies that try } \\
\text { to generate value for different } \\
\text { stakeholders, instead of } \\
\text { maximizing the value for the } \\
\text { shareholder. }\end{array}$ & $\begin{array}{l}\mathrm{R} \& \mathrm{D} \text { and technological innovation } \\
\text { are directed towards production } \\
\text { efficiency in terms of emissions } \\
\text { and waste. Environmental value } \\
\text { generation. }\end{array}$ \\
\hline 黛 & Importance of transparency and reporting. & $\begin{array}{l}\text { Trust is established among } \\
\text { stakeholders, because they are } \\
\text { taken into consideration in the } \\
\text { decision-making process. }\end{array}$ & $\begin{array}{l}\text { All stakeholders are aligned in } \\
\text { pursuing the same goal. }\end{array}$ \\
\hline 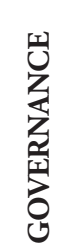 & $\begin{array}{l}\text { Promotion of democratic decision- } \\
\text { making considering employees and local } \\
\text { stakeholders, in fundamental strategic } \\
\text { issues. }\end{array}$ & $\begin{array}{l}\text { Board of directors makes decisions, } \\
\text { but their fiduciary duty is extended } \\
\text { to avoid shareholder primacy. }\end{array}$ & $\begin{array}{l}\text { The firm's owners (shareholders) } \\
\text { make decisions. }\end{array}$ \\
\hline
\end{tabular}

\section{Alternative Business Models: An Empirical Approach}

In this section, first, we will describe the methodology used to observe whether a group of experts share a consensus on the main characteristics of the new business models analyzed in the previous section (section 3 ). Second, we will present the results obtained from the empirical exploration. Finally, we will discuss those results.

\section{I Methodology}

In order to contrast the differences between the models analyzed in section 3, we used the Delphi methodology as a comparative tool, specifically the fuzzy Delphi analysis (Grisham, 2009). This tool benefits from a qualitative approach complemented with quantitative elements. Both approaches of the fuzzy Delphi method (qualitative and quantitative) were used to analyze the opinions of a group of experts and combine those opinions in a common vision (in this case, a closed numerical interval attached to each answer) which is shared by the aforementioned experts. In order to achieve this common vision, the experts had to review the numerical scores given by the other experts regarding the questions provided (see table 5). While the quantitative approach is present in the numerical scores provided by the group of experts, the qualitative approach is observed in some other features: the selection of the panel of experts, the search for a consensus as the final outcome, the importance of the opinions of experts, and the need to justify the divergences in those opinions when they are important (Förster \& von der Gracht, 2014).

In our case, this review process was anonymous in order to limit external influences and used questionnaires to make the systematization of answers possible (Alvarez, Calvo, \& Mora, 2014). In order to ensure the validity of the outcomes, the experts reviewed the process in three consecutive rounds (Cyphert \& Gant, 1971; Grisham, 2009). The results were statistically analyzed in an aggregated way using different metrics, such as central tendency metrics (median, mean), deviation (interquartile range, standard deviation), and frequency distribution (frequency histograms and polygons). In all the cases in which the range of the numerical answers was very wide, the experts were asked to explain the reasons for their divergent assessments (Förster \& von der Gracht, 2014).

In short, we carried out a fuzzy Delphi analysis in order to analyze whether these business models comply with the main characteristics of stakeholder theory (as stated in section 2). The results stem from a questionnaire that was 
delivered to a group of experts participating in the $3^{\text {rd }}$ permanent research seminar on the theory of the firm, held at the University of Deusto (Bilbao, Spain) in May 2015. This group of experts was composed of academics, practitioners, and policymakers from different European institutions (universities, firms, and public agencies) (see table 3).

Table 3

\section{Information about the experts}

\begin{tabular}{ccc}
\hline Expert & Type & Experience \\
\hline 1 & Academic & Professor in Finance \& Accounting \\
2 & Academic & Professor in Financial Economics \\
3 & Academic & Associate professor in Economics \\
4 & Academic & Assistant professor in Finance \& Accounting \\
5 & Practitioner & Legal representative of national corporation \\
6 & Practitioner & Advisor, human resources department of national corporation \\
7 & Practitioner & Chief executive of multinational corporation \\
8 & Policymaker & Advisor, public procurement for regional governments \\
9 & Policymaker & Member of the board of directors of a state-owned banking foundation \\
\hline
\end{tabular}

The variables were selected based on the recent work that Freeman and other academics have carried out on the creation of a new narrative for businesses based on stakeholder theory (Freeman \& Ginena, 2015; San-Jose et al., 2017). Those variables were studied in table 1 .

The first variable analyzed through the questionnaire was the dispersion of the organization's ownership among the different stakeholders. The second variable was the level of participation of these stakeholders in the company's governance. The third point studied was how these stakeholders participate in the firm, whether contractually or collaboratively. Fourth, the questionnaire asked about the degree of trust among the different stakeholders. The fifth variable was the extent of profit distribution; in those cases where profits are not distributed, the participants determined how the different models distribute the added value. Point 6 studied the centrality of the individual in the organization, i.e. whether the individual is considered as an instrument or an end. Seventh, we asked about the organization's environmental actions. The eighth variable was the type of value generated by the firm (economic or social) and, finally, the last variable was the number of primary interest groups in the organization (small or large number). Appendix A shows the questionnaire answered by the panel of experts.

All the questions were answered with scores ranging between 1 and 10. Questions 1, $2,4,5$, and 7 were given a score of 1 when the organization's dispersion of ownership, extent of profit distribution, degree of trust among stakeholders, and environmental concern were lowest and 10 when they were highest. Questions 3,6 , and 8 were given a score of 1 when there was a contractual form of participation, the individual was merely instrumental, and the value generated was primarily economic; and 10 when the organization was collaborative, the individual was an end, and the value generated was primarily social, respectively.

These variables can be considered as proxies to measure the six categories used to compare the different business models analyzed in section 3. Table 4 shows how these variables are linked to the categories used in section 3 . 
Table 4

\section{Categories and variables}

\begin{tabular}{cc}
\hline Category & Variables \\
\hline Goal of the firm & distribution of added value \\
\hline \multirow{2}{*}{ Property rights } & dispersion of ownership \\
\cline { 2 - 2 } Contractual ties & No. of primary interest groups \\
\hline Value generation & mode of participation \\
\hline Trust & type of value generated \\
\cline { 2 - 2 } & Centrality of the individual \\
\hline Governance & Concern for the environment \\
\hline
\end{tabular}

As stated before, the study was carried out following the fuzzy Delphi methodology in three consecutive rounds. In the first round, the participants had to provide answers based on their experience. In the second round, the average results of all the participants' answers were shared between them, so that they could reflect on the differences between their previous answers and the average values. They were able to give new scores or maintain their previous ones. This process was repeated in a third round.

\subsection{Results}

Table 5 shows the minimum, median, and maximum scores given by the experts for each variable analyzed in section 4.1 and for each alternative business model. These are the results obtained by the questionnaire after the third round. The empirical test allows us to draw two conclusions. First, the different business models that were analyzed focus on a limited number of stakeholders, but none of the models appears to be centered on all stakeholders. Thus, the sample does not corroborate the potential of stakeholder theory as a fully explanatory theory. However, three forms of organizing economic activity at the firm level achieved high scores for most of the variables (see table 5), meaning strong identification with the stakeholder approach: solidarity economy, social economy, and the economy of communion.

Table 5

\section{Results of the fuzzy Delphi analysis}

\begin{tabular}{|c|c|c|c|c|c|c|c|c|c|c|c|c|c|c|c|c|c|c|}
\hline \multirow{2}{*}{$\begin{array}{l}\text { Alternative business model/ } \\
\text { Variables } \\
\text { Dispersion of ownership }\end{array}$} & \multicolumn{3}{|c|}{$\begin{array}{l}\text { Economy of } \\
\text { communion }\end{array}$} & \multicolumn{3}{|c|}{$\begin{array}{c}\text { Social } \\
\text { economy }\end{array}$} & \multicolumn{3}{|c|}{$\begin{array}{l}\text { Solidarity } \\
\text { economy }\end{array}$} & \multicolumn{3}{|c|}{$\begin{array}{l}\text { Economy for } \\
\text { the common } \\
\text { good }\end{array}$} & \multicolumn{3}{|c|}{ B-corps } & \multicolumn{3}{|c|}{ Blue economy } \\
\hline & 2 & 4 & 6 & 4 & 5 & 7 & 3 & 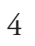 & 8 & 4 & 4 & 7 & 2 & & 4 & 3 & 4 & 5 \\
\hline Participation in governance & 4 & 5 & 6 & 6 & y & 7 & 0 & 0 & 9 & 4 & 4 & 7 & 2 & & 5 & 4 & 4 & 6 \\
\hline Mode of participation & 4 & 0 & 7 & 6 & 0 & 4 & 5 & r & 9 & 4 & 3 & 7 & 2 & 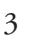 & 4 & 3 & J & 6 \\
\hline Degree of trust & 6 & 7 & 8 & 6 & 7 & 8 & 6 & 7 & 7 & 6 & 7 & 7 & 5 & & 7 & 5 & 6 & 6 \\
\hline Distribution of added value & 6 & 8 & 8 & 6 & 7 & 9 & 7 & 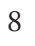 & 9 & 6 & 7 & 8 & 4 & & 6 & 4 & 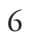 & 7 \\
\hline Centrality of the individual & 5 & 8 & 9 & 7 & 9 & 9 & 8 & 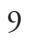 & 9 & 7 & 7 & 8 & 5 & & 7 & 5 & 6 & 6 \\
\hline Concern for the environment & 4 & 6 & 7 & $5=$ & 6 & 8 & 5 & 0 & 8 & 6 & 7 & 7 & 5 & 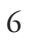 & 7 & 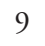 & 9 & 10 \\
\hline Type of value generated & 6 & 8 & 8 & 6 & 7 & 8 & 7 & 7 & 8 & 6 & 7 & 8 & 3 & & 6 & 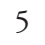 & 6 & 7 \\
\hline No. of primary interest groups & 2 & 3 & 3 & 2 & 3 & 5 & 3 & 4 & 5 & 4 & 5 & 5 & 4 & ) & 5 & 3 & 4 & 5 \\
\hline
\end{tabular}

In the following paragraphs we will present the results according to the linkages between variables and categories expressed in table 4. This will make the comparison between the theoretical part developed in sections 2 and 3 (tables 1 and 2) and the empirical one (section
4, table 5) easier to formulate. In relation to the goal of the firm, understood as total wealth generated beyond financial results, the first four business models achieve high scores (table 5). The experts understand that these business models have a wider distribution of profits or added value. 
Regarding ownership rights, in the second section we studied that while shareholder theory limited ownership rights to capital resources, stakeholder theory considered the rights of the rest of the firm's resources. The results show that the variable 'number of primary interest groups' scores quite low values, and consistently with this, dispersion of ownership also scores low levels.

Regarding contractual ties, shareholder theory is based on a logic of law, while stakeholder theory follows a logic of exchange. The experts give higher scores to social economy (8), solidarity economy (7), and EC (6), concluding that these business models have a more collaborative mode of participation. In relation to value generation (economic or social), according to the type of value, EC (8), social, and solidarity economies, and ECG (7) score the highest values.

In section 2, we explained trust in the firm comparing agency and stewardship theories. The variables 'degree of trust' and 'centrality of the individual' (instrumental vs individual as an end) show high scores in the first four business models, while concern for the environment scores the highest value for the blue economy (9). Finally, regarding governance, a stakeholder approach should promote multi-stakeholder governance understanding that it is not only financial capital in the resources that generates value. In this case, solidarity economy (8) and social economy (7) score the highest results.

\section{$4 \cdot 3$ Discussion}

In our empirical analysis (section 4), we try to assess if the six business models that we identified in the bibliographical analysis might be successful vehicles for making the paradigm shift from the shareholder model to stakeholder theory. Thus, in the next paragraphs we will discuss this possibility.

The variable for which the six business models analyzed received the highest scores was centrality of the individual, which is a key element for these types of firms and a key issue in the organization of economic activity proposed by stakeholder theory (see section 2). In general, according to the experts, all business models considered have a certain dispersion of ownership and a broad participation in governance, care about the environment, generate social value, and are engaged with more than one interest group (see table 5). These characteristics place them close to the stakeholder approach. This means that they are not only open to shareholders, but also to other interest groups in terms of ownership, participation in governance, and the creation of value for society at large. Although there is not a perfect alignment between these models and stakeholder theory, the group of experts do recognize that, to different extents, the models share some of the key elements of stakeholder theory (see table 5).

Regarding profits, most business models back company proposals that pursue economic profit. Profit is consistent with the stakeholder approach, but short-term profit maximization focused only on shareholders is not. According to the panel of experts, the emerging business models considered in the analysis are consistent with the introduction of ethical, environmental, and social principles regarding the organizational structure of the firm.

In addition, and according to the panel of experts, three of them rank higher in terms of identification with the stakeholder approach: solidarity economy, social economy, and the economy of communion.

\section{Conclusions}

The dominant paradigm regarding business management, based on shareholder interests, has limitations. Those limitations are creating a gap between the interests of corporations and social well-being. In order to overcome them, a paradigm shift is essential, involving a change from a system based on shareholder profit maximization to a system where value is broadly distributed among stakeholders. Regarding the first objective of this paper, we compared the main 
characteristics of both the shareholder approach and stakeholder theory, and we identified and explained six business models that may overcome some of the limitations of the shareholder model.

In relation to the second objective of the paper, we analyzed the answers provided by the panel of experts through a fuzzy Delphi process, identifying three business models that overcome the limitations of the shareholder model and are aligned to a great extent with stakeholder theory. Corporations and managers which are interested in aligning the goals of the corporation with the interests of all stakeholders can find in those three business models (solidarity economy, social economy, and economy of communion) helpful characteristics to close the gap between social and business interests. In addition, the identification of this convergence between those three models and stakeholder theory enables the search for reference cases to illustrate the possibility of the new narrative for business based on stakeholder theory. At the same time, it allows managers to examine how those firms achieve that convergence, which makes practical learning possible. The finding of business models that respond to the main principles of stakeholder theory in its non-instrumental perspective can make a comparison possible between the theory and reality, and facilitate new empirical contrasts in the domain of stakeholder theory. Theoretical and empirical hypotheses which state that corporations oriented towards stakeholders are able to distribute more value between them can now be empirically analyzed. At the same time, it might be possible to compare correlations that link corporations oriented towards stakeholders with different economic and financial variables.

Two lines of research can be explored based on this work. On one hand, it could be helpful to compare the perceptions of the panel of experts with an analysis of existing firms belonging to the six business models. This comparison could help in validating the results given by the panel of experts and, at the same time, collecting actual data that may support (or reject) the conclusions offered in this paper. On the other hand, the panel of experts presents a geographical limitation: all its members are based on the European continent. A more international panel of experts could have expressed different opinions. Therefore, a study of differences between business models according to political, social, and geographical characteristics may be helpful to explore possible conditioning factors in the development of emerging business models that might be country-specific.

\section{References}

Agle, B. R., Donaldson, T., Freeman, E., Jensen, M. C., Mitchell, R. K., \& Wood, D. J. (2008). Dialogue: Toward superior stakeholder theory. Business Ethics Quarterly 18(2), 162-166.

Aguado, R., Alcaniz, L., \& Retolaza, J.L. (2015). A new role for the firm incorporating sustainability and human dignity. Conceptualization and measurement. Human Systems Management, 34(1), 43-56.

Álvarez, I., Calvo, J. A., \& Mora, A. (2014). Involving academics in the accounting standard setting process: An application of the Delphi methodology to the assessment of IASB proposals. Journal of Management \& Governance, 18(3), 765-791.

André, R. (2012). Assessing the accountability of the benefit corporation: Will this new gray sector organization enhance corporate social responsibility? Journal of Business Ethics, 110(1), 133-150.

Bacchiega, A., \& Borzaga, C. (2003). The economics of the third sector: Towards a more comprehensive approach. In H. K. Anheier, \& A. Ben-Ner (Eds.), The Study of The Nonprofit Enterprise, Theories and Approaches (pp. 27-48). Dordrecht: Kulwer.

Barnett, R. E. (1986). A consent theory of contract. Columbia Law Review, 86(2), 269-321. 
Bcorp. (2014). Annual Report 2014. Retrieved from https://www.bcorporation.net/news-media/ annual-report-2014.

Bruni, L., \& Zamagni, S. (2004). The economy of communion: Inspirations and achievements. Finance \& The Common Good/Bien Comun, 20, 91-97.

Coase, R. H. (1937). The nature of the firm. Economica, 4(16), 386-405.

Coase, R. H. (1960). Problem of social cost. In C. Gopalakrishnan, Classic Papers in Natural Resource Economics (pp. 87-137). UK: Palgrave Macmillan.

Cyphert, F. R., \& Gant, W. L. (1971). The Delphi technique: A case study. Phi Delta Kappa, 52(5), 272-273.

Dacheux, E., \& Goujon, D. (2011). The solidarity economy: An alternative development strategy? International Social Sciences Journal, 62(203-204), 205-215.

Demsetz, H. (1967). Toward a theory of property rights. The American economic review, 347-359.

Donaldson, T., \& Preston, L. E. (1995). The stakeholder theory of the corporation: Concepts, evidence, and implications. The Academy of Management Review, 20(1), 65-91.

Dunham, L., Freeman, R. E., \& Liedtka, J. (2006). Enhancing stakeholder practice: A particularized exploration of community. Business Ethics Quarterly, 16(1), 23-42.

Elkington, J. (1998). Partnerships from cannibals with forks: The triple bottom line of 21 st-century business. Environmental Quality Management, 8(1), 37-51.

European Network of Social Economy Foundations (2000). Charter of the European Network of Social Economy Foundations. Brussels: European Network of Social Economy Foundations.
Retrieved from https://www.eesc.europa.eu/ resources/docs/qe-30-12-790-en-c.pdf

Felber, C. (2015). Change everything. Chicago: University of Chicago Press Economics Books.

Förster, B., \& von der Gracht, H. (2014). Assessing Delphi panel composition for strategic foresight: A comparison of panels based on company-internal and external participants. Technological Forecasting and Social Change, 84, 215-229.

Freeman, R. E. (1984). Strategic management: $A$ stakeholder approach. Boston: Pitman

Freeman, R.E. (1999). Divergent stakeholder theory. Academy of Management Review, 24(2), 233-236.

Freeman, R. E. (2008). II. Ending the So-Called "Friedman-Freeman" Debate. In B. R. Agle, T. Donaldson, R. E. Freeman, M. C. Jensen, R. K. Mitchell, \& D. J. Wood (2008). Dialogue: Toward superior stakeholder theory, Business Ethics Quarterly, 18(2), 162-166.

Freeman, R.E., \& Ginena, K. (2015). Rethinking the purpose of the corporation: Challenges from stakeholder theory. Notizie di Politeia, 117, 9-18

Freeman, R. E., Harrison, J. S., Wicks, A. C., Parmar, B., \& De Colle, S. (2010). Stakeholder theory. The state of the art. New York: Cambridge University Press.

Freeman, R. E., \& Liedtka, J. (1991). Corporate social responsibility: A critical approach. Business Horizons, 34(4), 92-99.

Freeman, R. E., Kirsten, M., \& Parmar, B. (2007). Stakeholder capitalism. Journal of Business Ethics, 74(4), 303-314.

Freeman, R. E., Stewart, L., \& Moriarty, B. (2009). Teaching business ethics in the age of Madoff Change. The Magazine of Higher Learning, 41(6), 37-42. 
Friedman, M. (1970). The social responsibility of business is to increase its profits. In R. Chadwick, \& D. Schroeder, Applied ethics: critical concepts in philosophy. London: Routledge.

Garriga, E., \& Melé, D. (2004). Corporate social responsibility theories: Mapping the territory. Journal of Business Ethics 53(1), 51-71.

Gold, L. (2013). Economy of communion. In L. Bruni, \& S. Zamagni (Eds.), Handbook on the Economics of Reciprocity and Social Enterprise (pp. 112-120). Cheltenham (UK): Edward Elgar Publishing Limited.

Grisham, T. (2009). The Delphi technique: A method for testing complex and multifaceted topics. International Journal of Managing Projects in Business, 2(1), 112-130.

Guitián, G. (2010). Integral subsidiarity and economy of communion: Two challenges from Caritas in Veritate. Journal of Markets \& Morality, 13(2), 279-295.

Héjj, T. (2011). The economy of sharing. In L. Zsolnai, (Ed.), Spirituality and Ethics in Management (pp. 151-161). Netherlands: Springer.

Hiller, J. S. (2013). The benefit corporation and corporate social responsibility. Journal of Business Ethics, 118(2), 287-301.

Jensen, M. C., \& Meckling, W. H. (1976). Theory of the firm: Managerial behavior agency cost, and ownership structure. Journal of Financial Economics, 3, 305-360.

Jensen, M. C. (2001). Value maximization, stakeholder theory, and the corporate objective function. Journal of applied corporate finance, 14(3), 8-21.

Keay, A. (2007). Tackling the issue of the corporate objective: An analysis of the United Kingdom's enlightened shareholder value approach. Sydney L. Rev., 29, 577 .
Lewis, M., \& Swinney, D. (2008). Social economy \& solidarity economy: Transformative concepts for unprecedented times. In J. Allard, C. Davidson, \& D. Matthaei (Eds.) Solidarity Economy: Building alternatives for People and Planet (pp. 28-41). Chicago (USA): ChangeMaker Publications.

Lubich, Ch. (2007). Essential Writings: Spirituality, Dialogue, Culture. New York: New City Press.

Melé, D., \& Schlag, M. (eds). (2015). Humanism in Economics and Business. Perspectives of the catholic Social Tradition. New York: Springer.

Monzón, J.L., \& Chaves, R. (2012). The social economy in the European Union. Brussels: European Economic and Social Committee.

Naughton, M. (2015). Thinking Institutionally about Business: Seeing its Nature as a Community of Persons and its Purpose as the Common Good. In D. Melé \& M. Schlag (eds). Humanism in Economics and Business. Perspectives of the Catholic Social Tradition, (pp. 179-199). New York: Springer.

Pauli, G.A. (2010). The blue economy: 10 years, 100 innovations, 100 million jobs. New Mexico: Paradigm Publications.

Pauli, G.A. (2015). The blue economy. Version 2.0. New Delhi: Academic Foundation.

Retolaza, J. L., Mugarra, A., \& Enciso, M. (2005). Solidarity-based enterprises: New comprising concept for the enterprise of the future. In R. Chaves, J.L. Monzón, Y. Stryjan, \& R. Apear (Eds): The Future of Cooperatives in a Growing Europe, (pp. 277-304). España: CIRIEC.

San-Jose, L., Retolaza, J.L., \& Freeman, E. (2017). Chapter 13: Stakeholder engagement at etxanobe: A case study of the new story of business. In J. Kujala, Sach, \& E. Freeman (Eds.): Stakeholder Engagement: Clinical Research Cases. Springer. 


\section{Appendix A - Questionnaire}

1. Score from 1 (minimum) to 10 (maximum) the dispersion of the ownership of the organization among the different interest groups.

\begin{tabular}{|c|c|c|c|c|c|}
\hline $\begin{array}{l}\text { Economy of } \\
\text { communion }\end{array}$ & Social economy & $\begin{array}{c}\text { Economy of } \\
\text { solidarity }\end{array}$ & $\begin{array}{l}\text { Economy of the } \\
\text { common good }\end{array}$ & B-corp & Blue economy \\
\hline & & & & & \\
\hline
\end{tabular}

2. Score from 1 (minimum) to 10 (maximum) the wideness of the participation of the different interest groups in the governance of the organization.

\begin{tabular}{|c|c|c|c|c|c|}
\hline $\begin{array}{l}\text { Economy of } \\
\text { communion }\end{array}$ & Social economy & $\begin{array}{c}\text { Economy of } \\
\text { solidarity }\end{array}$ & $\begin{array}{l}\text { Economy of the } \\
\text { common good }\end{array}$ & B-corp & Blue economy \\
\hline & & & & & \\
\hline
\end{tabular}

3. Score from 1 (contractual) to 10 (collaborative) the mode of participation of the different interest groups of the organization.

\begin{tabular}{|c|c|c|c|c|c|}
\hline $\begin{array}{l}\text { Economy of } \\
\text { communion }\end{array}$ & Social economy & $\begin{array}{c}\text { Economy of } \\
\text { solidarity }\end{array}$ & $\begin{array}{l}\text { Economy of the } \\
\text { common good }\end{array}$ & B-corp & Blue economy \\
\hline & & & & & \\
\hline
\end{tabular}

4. Score from 1 (minimum) to 10 (maximum) the degree of trust among the different interest groups of the organization.

\begin{tabular}{|c|c|c|c|c|c|}
\hline $\begin{array}{l}\text { Economy of } \\
\text { communion }\end{array}$ & Social economy & $\begin{array}{c}\text { Economy of } \\
\text { solidarity }\end{array}$ & $\begin{array}{l}\text { Economy of the } \\
\text { common good }\end{array}$ & B-corp & Blue economy \\
\hline & & & & & \\
\hline
\end{tabular}

5. Score from 1 (minimum) to 10 (maximum) the extent of the distribution of profits. (If the organization does not distribute profits, consider the distribution of added value).

\begin{tabular}{|c|c|c|c|c|c|}
\hline $\begin{array}{l}\text { Economy of } \\
\text { communion }\end{array}$ & Social economy & $\begin{array}{c}\text { Economy of } \\
\text { solidarity }\end{array}$ & $\begin{array}{l}\text { Economy of the } \\
\text { common good }\end{array}$ & B-corp & Blue economy \\
\hline & & & & & \\
\hline
\end{tabular}

6. Score from 1 (instrumental) to 10 (individual as an end) the centrality of the individual in the organization.

\begin{tabular}{|c|c|c|c|c|c|}
\hline $\begin{array}{l}\text { Economy of } \\
\text { communion }\end{array}$ & Social economy & $\begin{array}{c}\text { Economy of } \\
\text { solidarity }\end{array}$ & $\begin{array}{l}\text { Economy of the } \\
\text { common good }\end{array}$ & B-corp & Blue economy \\
\hline & & & & & \\
\hline
\end{tabular}

7. Score from 1 (minimum) to 10 (maximum) the organization's concern for the environment.

\begin{tabular}{|c|c|c|c|c|c|}
\hline $\begin{array}{l}\text { Economy of } \\
\text { communion }\end{array}$ & Social economy & $\begin{array}{c}\text { Economy of } \\
\text { solidarity }\end{array}$ & $\begin{array}{l}\text { Economy of the } \\
\text { common good }\end{array}$ & B-corp & Blue economy \\
\hline & & & & & \\
\hline
\end{tabular}

8. Score from 1 (economic value) to 10 (social value) the type of value generated by the organization.

\begin{tabular}{|c|c|c|c|c|c|}
\hline $\begin{array}{l}\text { Economy of } \\
\text { communion }\end{array}$ & Social economy & $\begin{array}{c}\text { Economy of } \\
\text { solidarity }\end{array}$ & $\begin{array}{l}\text { Economy of the } \\
\text { common good }\end{array}$ & B-corp & Blue economy \\
\hline & & & & & \\
\hline
\end{tabular}

9. Indicate the number of interest groups that are primary for the organization.

\begin{tabular}{|c|c|c|c|c|c|}
\hline $\begin{array}{l}\text { Economy of } \\
\text { communion }\end{array}$ & Social economy & $\begin{array}{c}\text { Economy of } \\
\text { solidarity }\end{array}$ & $\begin{array}{l}\text { Economy of the } \\
\text { common good }\end{array}$ & B-corp & Blue economy \\
\hline & & & & & \\
\hline
\end{tabular}




\section{Authors:}

1. Leire Alcaniz, PhD in Business Administration, University of Deusto (university of study), Bilbao, Spain. E-mail: leire.alcaniz@deusto.es

\section{ORCID}

(iD) 0000-0002-4765-7953

2. Ricardo Aguado, PhD in Applied Economics, University of the Basque Country (university of study), Bilbao, Spain.

E-mail:ricardo.aguado@deusto.es

ORCID

(iD) 0000-0002-2671-5691

3. Jose Luis Retolaza (university of study), Bilbao, Spain.

E-mail:joseluis.retolaza@deusto.es

ORCID

(iD 0000-0001-7089-4861

\section{Contribution of each author}

\begin{tabular}{|c|c|c|c|}
\hline Contribution & Leire Alcaniz & Ricardo Aguado & Jose Luis Retolaza \\
\hline 1. Definition of research problem & $\sqrt{ }$ & $\sqrt{ }$ & $\sqrt{ }$ \\
\hline 2. Development of hypotheses or research questions (empirical studies) & $\sqrt{ }$ & $\sqrt{ }$ & $\sqrt{ }$ \\
\hline 3. Development of theoretical propositions ( theoretical Work ) & & $\sqrt{ }$ & $\sqrt{ }$ \\
\hline 4. Theoretical foundation/ Literature review & $\sqrt{ }$ & $\sqrt{ }$ & $\sqrt{ }$ \\
\hline 5. Definition of methodological procedures & $\sqrt{ }$ & & $\sqrt{ }$ \\
\hline 6. Data collection & $\sqrt{ }$ & & \\
\hline 7. Statistical analysis & $\sqrt{ }$ & & \\
\hline 8. Analysis and interpretation of data & $\sqrt{ }$ & & \\
\hline 9. Critical revision of the manuscript & & $\sqrt{ }$ & \\
\hline 10. Manuscript Writing & $\sqrt{ }$ & $\sqrt{ }$ & $\sqrt{ }$ \\
\hline 11. Other (please specify which) & & & \\
\hline
\end{tabular}

